\title{
TWO SEQUENTIAL PCR AMPLIFICATIONS FOR DETECTION OF Schistosoma mansoni IN STOOL SAMPLES WITH LOW PARASITE LOAD
}

\author{
Maria Cristina Carvalho do ESPÍRITO-SANTO(1), Mónica Viviana ALVARADO-MORA(2), Pedro Luiz Silva PINTO(3), Flair José CARRILHO(4), \\ João Renato Rebello PINHO(2) \& Ronaldo Cesar Borges GRYSCHEK(1)
}

\begin{abstract}
SUMMARY
Schistosomiasis constitutes a major public health problem, with an estimated 200 million individuals infected worldwide and 700 million people living in risk areas. In Brazil there are areas of high, medium and low endemicity. Studies have shown that in endemic areas with a low prevalence of Schistosoma infection the sensitivity of parasitological methods is clearly reduced. Consequently diagnosis is often impeded due to the presence of false-negative results. The aim of this study is to present the PCR reamplification (Re-PCR) protocol for the detection of Schistosoma mansoni in samples with low parasite load (with less than 100 eggs per gram (epg) of feces). Three methods were used for the lysis of the envelopes of the $S$. mansoni eggs and two techniques of DNA extraction were carried out. Extracted DNA was quantified, and the results suggested that the extraction technique, which mixed glass beads with a guanidine isothiocyanate/phenol/chloroform (GT) solution, produced good results. PCR reamplification was conducted and detection sensitivity was found to be five eggs per $500 \mathrm{mg}$ of artificially marked feces. The results achieved using these methods suggest that they are potentially viable for the detection of Schistosoma infection with low parasite load.
\end{abstract}

KEYWORDS: S. mansoni; PCR reamplification; Eggs; Human feces; Diagnosis.

\section{INTRODUCTION}

Schistosomiasis is a major public health problem, with an estimated 200 million individuals infected worldwide, of whom 120 million are symptomatic and 20 million have severe forms of the disease. Seven hundred million people are at risk of infection by six species that can infect humans ${ }^{2}$.

In Brazil, the only species of medical and sanitary interest is Schistosoma mansoni ${ }^{16}$. Schistosomiasis mansoni is considered an endemic disease in 19 Federative Units. For this reason, the Brazilian Ministry of Health aims to reduce the occurrence of the severe forms of the disease and the number of deaths caused by it, as well as to reduce the prevalence of infection and the risk of geographic expansion of the disease ${ }^{1}$.

Parasitological methods continue to be the gold standard for laboratory diagnosis of this parasitosis. However, despite being less costly and technically simple, these diagnostic techniques lack sensitivity in areas of low prevalence (prevalence below $10 \%$, with most infected asymptomatic subjects, eliminating less than 96 eggs/gram of feces) of schistosomiasis $^{6,17}$.

Thus, diagnosis of schistosomiasis requires the use of more sensitive techniques than the search for eggs in feces, both in areas of low endemicity and for the evaluation of parasitologic cure after treatment. This is important from the epidemiologic view, because the permanence of infected individuals with false-negative results in coproscopic inquiries is enough to continue the risk of transmission, even after suitable interventions are carried out by means of sanitary measures ${ }^{18}$.

Extraction of the sample DNA is an important stage when carrying out molecular techniques. There are several different kits for extracting DNA from blood, urine, solid tissues and fecal samples. Among biological samples, feces pose the greatest problems for DNA extraction and require the development of new strategies, especially when searching for $S$. mansoni eggs because they have complex shells that are not easily removed by chemical digestion ${ }^{5}$. Hence, the aim of this study is to present the PCR reamplification protocol for the detection of $S$. mansoni in samples with low parasite load (with few numbers of eggs per gram (epg) of feces).

\section{MATERIAL AND METHODS}

Laboratory cycle of $S$. mansoni: The biologic cycle of $S$. mansoni is maintained in the Laboratory of Immunopathology of Schistosomiasis (LIM-06) of the Institute of Tropical Medicine of the University of

(1) Department of Infectious and Parasitic Diseases, School of Medicine, University of São Paulo, São Paulo, SP, Brazil (LIM-06). E-mails: cristinasanto@usp.br; rcbgry@ usp.br

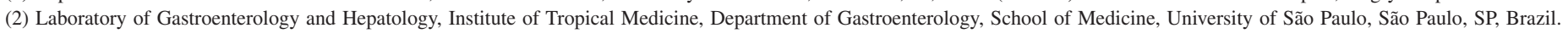
E-mails: monica.viviana@usp.br; jrrpinho@usp.br

(3) Enteroparasitosis Section of the Parasitology and Mycology Division, Adolfo Lutz Institute, São Paulo, SP, Brazil. E-mail: pedro.luiz44@terra.com.br

(4) Department of Gastroenterology, School of Medicine, University of São Paulo, São Paulo, SP, Brazil. E-mail: fjcarril@usp.br

Correspondence to: Maria Cristina Espírito-Santo. E-mail: cristinasanto@usp.br 


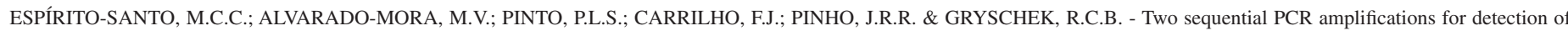
Schistosoma mansoni in stool samples with low parasite load. Rev. Inst. Med. Trop. Sao Paulo, 54(5): 245-8, 2012.

São Paulo, Brazil, by infecting hamsters (Mesocricetus auratus) and Biomphalaria glabrata snails (BH strain) periodically. Animals that had been subcutaneously infected with 200-300 cercariae of $S$. mansoni were sacrificed six to seven weeks after the infection in order to collect the parasite eggs from their livers and intestines. The methodology implemented was in compliance with the National Animal Ethics Guidelines, COBEA (Comitê Brasileiro de Experimentação Animal).

Extraction and cleaning of $S$. mansoni eggs from liver and intestine of hamsters: The extraction and cleaning of $S$. mansoni eggs was performed according to DESDREN \& PAYNE ${ }^{7}$ and PINTO et $a l .{ }^{14}$. The livers and intestines of three hamsters were minced into small pieces and ground in a blender with $1.4 \%$ saline solution. Thereafter, the sediment was passed sequentially through metal mesh (Granust) sieves: $\mathrm{N}^{\circ} 100(0.150 \mathrm{~mm}), \mathrm{N}^{\circ} 200(0.75 \mathrm{~mm})$ and $\mathrm{N}^{\circ} 400(0.038 \mathrm{~mm})$ for the complete removal of liver and intestine tissues. The eggs retained in the latter sieve were then removed by successive rinsing with $1.4 \%$ saline solution, and observed and counted by light microscopy. A solution containing 150,000 eggs/mL was obtained for the standardization of the DNA extraction method, and another solution containing 1,380 eggs $/ \mathrm{mL}$ was obtained for the standardization of PCR reamplification.

DNA extraction methods: In order to obtain the highest amount of DNA from the $S$. mansoni eggs, three different physical methods and two techniques of DNA extraction were tested.

DNA extraction of $S$. mansoni eggs - DNA extraction was carried out using $1,200 \mu \mathrm{L}$ of PBS solution $(0.01 \mathrm{M})$ containing 150,000 eggs $/ \mathrm{mL}$. Six aliquots of $200 \mu \mathrm{L}$ were prepared from the PBS solution: 1) two aliquots were placed in liquid nitrogen for one minute, incubated at $95{ }^{\circ} \mathrm{C}$ for one minute, placed in liquid nitrogen for one minute and incubated at $95^{\circ} \mathrm{C}$ for five minutes; 2) two aliquots were put into a whirlpool with five glass beads for five minutes; 3) two aliquots were put into a whirlpool with $0.1 \mathrm{mg}$ of glass fiber for five minutes. DNA extraction was then carried out with $\mathrm{GT}^{3}$ in one of the two aliquots from each test, whereas QIAamp® DNA Stool Mini Kit was used in the other aliquot. After extraction the DNA was quantified in duplicate by NanoDrop (ND-1000 Spectrophotometer V3.5).

\section{DNA extraction of $S$. mansoni eggs in feces and detection of two sequential PCR amplifications}

Preparation of fecal samples artificially marked with S. mansoni eggs - Fresh human fecal samples negative for $S$. mansoni, using the Kato-Katz and Hoffman methods (two slides for each technique), were obtained from the Central Laboratory of Hospital das Clínicas (Medical School of the University of São Paulo). Seven samples were prepared in $2 \mathrm{~mL}$ tubes, each containing $500 \mathrm{mg}$ of feces. A measuring plate of stainless steel was used for determining the weight of the fecal samples, which was $40 \times 37 \mathrm{~mm}$ thick and had a central orifice of $14.1 \mathrm{~mm}$ in diameter developed to ensure the approximate weight of $500 \mathrm{mg}$ of feces.

The solution containing 1,380 eggs/mL was used in this test. Through direct observation by light microscopy and using an Olympus-CX41 microscope, the eggs were counted and five volumes of the solution containing 5, 10, 20, 30 and 50 eggs/mL were added into five of the seven $2 \mathrm{~mL}$ tubes. Similarly, a positive control containing 1,000 eggs/ $\mathrm{mL}$ was used, in addition to a negative control.
DNA extraction from feces artificially marked with $S$. mansoni eggs - The total DNA of $500 \mathrm{mg}$ of feces artificially marked with $S$. mansoni eggs was extracted using the $\mathrm{GT}^{3}$ extraction technique, and modified by adding five glass beads in each $2 \mathrm{~mL}$ plastic tube.

The extraction was carried out in two stages: 1) each sample was resuspended in $500 \mu \mathrm{L}$ of ASL Buffer from the QIAamp® DNA Stool Mini Kit. Five glass beads were added and homogenized for five minutes. Subsequently, $400 \mu \mathrm{L}$ of the supernatant was removed and added to another tube containing $200 \mu \mathrm{L}$ of AL Buffer and $30 \mu \mathrm{L}$ of proteinase K (QIAamp® DNA Stool Mini Kit). The samples, prepared as described, were incubated at $37{ }^{\circ} \mathrm{C}$ for 12 hours. 2) $300 \mu \mathrm{L}$ of GT and $50 \mu \mathrm{L}$ of chloroform at $-20^{\circ} \mathrm{C}$ were added to each sample, followed by homogenization and incubation for 10 minutes and centrifugation at 13,200 rpm. The supernatant was transferred to another tube and precipitated with $300 \mu \mathrm{L}$ of isopropanol at $-20^{\circ} \mathrm{C}$. Once the DNA was precipitated, the isopropanol was discarded and $300 \mu \mathrm{L}$ of ethanol absolute was added, followed by centrifugation at 13,200 rpm. Finally, the ethanol was discarded and the samples were incubated at $95{ }^{\circ} \mathrm{C}$ for one minute and resuspended in $100 \mu \mathrm{L}$ of DEPC-treated Milli-Q water. The extracted DNA was stored at $-20^{\circ} \mathrm{C}$.

Amplification of the S. mansoni DNA - Once the DNA extraction was carried out the samples were submitted to two sequential amplifications by PCR.

Primers that amplify a 121 bp tandem repeat DNA fragment of the $S$. mansoni genome were used for the amplification of this region previously cited by PONTES et al. ${ }^{15}$. Bovine Serum Albumin-(BSA) (SIGMA, USA) was also added in order to neutralize the action of any inhibitors that could be present at the fecal samples ${ }^{11}$.

The first PCR reactions were performed in a final volume of 40 $\mu \mathrm{L}$ under the following conditions: $1 \mathrm{X}$ Buffer (10X), $2.5 \mathrm{mM} \mathrm{MgCl}$, $0.4 \mathrm{mM}$ of each dNTP $(10 \mathrm{mM}), 0.6 \mathrm{pmol} / \mu \mathrm{L}$ of each primer, $0.1 \mu \mathrm{g} /$ $\mu \mathrm{L}$ BSA, $2.0 \mathrm{U}$ of Platinum Taq DNA polymerase (Invitrogen TM Life Technologies, Carlsbad, CA, USA) and $10 \mu \mathrm{L}$ of DNA. The second PCR was performed under the same conditions plus $7 \mu \mathrm{L}$ of amplified DNA from the first reaction. The PCR program used had been described by GOMES et al., 2009 ${ }^{11}$. The detection of the amplified DNA was performed by electrophoresis in $2.5 \%$ agarose gel, which was stained with ethidium bromide and Low Mass Ladder in order to check the size of the amplicon generated.

A $120 \mathrm{bp}$ fragment of the gene encoding human beta actin (ACTB) was amplified, as an internal control of the DNA extraction with the previously described primers Aco1 and Aco2 ${ }^{12}$. The amplification conditions were performed according to GOMES et al., $2010^{10}$.

Purification and sequencing of the positive control - The amplified DNA from the positive control (sample with 1,000 eggs $/ \mathrm{mL}$ ) was purified using the ChargeSwitch ${ }^{\circledR}$ PCR Clean-Up Kit. The sequencing was then carried out in the ABI Prism ${ }^{\circledR} 3100$ Automatic Sequencer (Applied Biosystems, Foster City, CA, USA) using deoxynucleotide triphosphates (dNTPs) with fluorescent markers (Big Dye ${ }^{\circledR}$ Terminator v3.1 Cycle Sequencing Ready Reaction kit - Applied Biosystems, Foster City, CA, USA). In order to obtain the consensus sequence, the forward and reverse sequences obtained were initially analyzed using the Phred-Phrap-Consed 


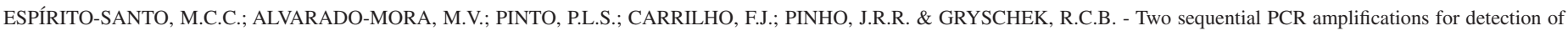
Schistosoma mansoni in stool samples with low parasite load. Rev. Inst. Med. Trop. Sao Paulo, 54(5): 245-8, 2012

programs $^{8,9}$. The consensus sequence was observed, analyzed and edited using the SE-AL program (available at: http://tree.bio.ed.ac.uk/software/ seal/). Finally, a BLAST was performed to confirm that the obtained sequence belonged to the expected fragment of the $S$. mansoni genome.

\section{RESULTS}

DNA extraction method: The sample initially containing 150,000 eggs/mL was homogenized and six samples with approximately 30,000 eggs $/ \mathrm{mL}$ were taken from it and prepared. After DNA extraction, the DNA obtained was quantified using the ND-1000 Spectrophotometer V3.5. The quantification results were: liquid nitrogen/GT $=181 \mathrm{ng} / \mu \mathrm{L}$; liquid nitrogen/extraction kit $=9 \mathrm{ng} / \mu \mathrm{L} ;$ milled glass $/ \mathrm{GT}=313.2 \mathrm{ng} / \mu \mathrm{L}$; milled glass/extraction kit $=60.9 \mathrm{ng} / \mu \mathrm{L}$; glass beads $/ \mathrm{GT}=437.9 \mathrm{ng} / \mu \mathrm{L}$; glass beads/extraction kit $=106.6 \mathrm{ng} / \mu \mathrm{L}$.

Detection of $S$. mansoni DNA through PCR reamplification: Once the standardization of the DNA extraction technique was performed, the method for the detection of $S$. mansoni DNA was developed for samples with low parasite load. All the dilutions tested (5, 10, 20, 30 and 50 eggs/mL) were amplified by two sequential reactions of the same DNA fragment (Fig. 1). Similarly, the $120 \mathrm{bp}$ fragment of the internal control (ACTB) was amplified in all the samples, including the negative control, and finally the sequence obtained was considered to be the one from the positive control.

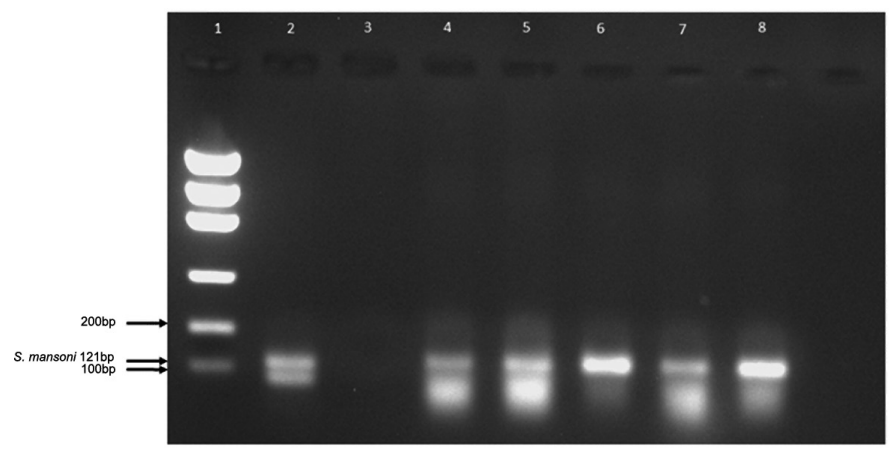

Fig. 1 - Detection of $S$. mansoni DNA by two sequential PCR amplifications: (1) Low DNA Mass Ladder; (2) Positive Control (1,000 eggs/mL); (3) Negative Control; (4) Sample 1 (5 eggs/mL); (5) Sample 2 (10 eggs/mL); (6) Sample 3 (20 eggs $/ \mathrm{mL})$; (7) Sample 4 (30 eggs/ $\mathrm{mL})$; (8) Sample 5 (50 eggs $/ \mathrm{mL})$.

\section{DISCUSSION}

The development of laboratory tools for the diagnosis of infections with low parasite load is one of the priorities in the schistosomiasis research agenda of the World Health Organization's control programs. Among these tools, the research agenda points to the development and standardization of molecular methods for the surveillance of infections in humans and snails which can be applied to individual and public health studies ${ }^{4}$.

In the present study, a new DNA extraction technique was implemented, followed by PCR reamplification (two sequential amplifications of the same PCR fragment), with the detection of the amplified fragment in $2.5 \%$ agarose gel. This is a sensitive method, its detection limit was $5 \mathrm{eggs} / 500 \mathrm{mg}$ of artificially marked feces, which represents the equivalent of 0.4 eggs $/ 40 \mathrm{mg}$ of feces, according to the Kato-Katz method or an estimate of 9.6 eggs/gram of feces.

The PCR analytical sensitivity was evaluated by 5 -fold dilutions extracted from $500 \mathrm{mg}$ stool samples each labeled as having artificially added 5, 10, 20, 30 and 50 eggs/mL of $S$. mansoni.

The detection limit was 5 eggs/500 mg, approximately $43 \mathrm{fg}$ of genomic DNA extracted from the eggs of $S$. mansoni.

The first study conducted with fecal samples and serum revealed that the conventional PCR can detect $2.4 \mathrm{fg}$ of DNA of $S$. mansoni per gram of feces, which makes this method more sensitive than the KatoKatz method ${ }^{15}$.

More recently, other studies have been trying to improve the sensitivity of molecular methods. GOMES et al., 2009 ${ }^{11}$, achieved a detection limit of $3 \mathrm{fg}$ of DNA from $S$. mansoni in feces. OLIVEIRA et al..$^{13}$ obtained sensitivity using the conventional PCR of an egg in a suspension of $300 \mu \mathrm{L}$ of feces. Eventually, GOMES et al., 2010 ${ }^{10}$, obtained a sensitivity of 0.15 eggs/gram of feces ( $1.3 \mathrm{fg}$ of DNA), using the PCR-ELISA detection system. Although these studies may report DNA detection values in lower concentrations, it is important to consider that the observation of the bands of DNA concentration may not be suitable for use in routine diagnosis of this infection.

It is important to highlight that the PCR reamplification may show a high level of amplicon contamination when it is not performed under suitable laboratory conditions. Similarly, one must bear in mind that for the diagnosis of the infection the amplified DNA band in the gel, as a final product of the test, should be sufficiently intense in order to ensure the presence of the pathogen in the sample. Thus the DNA bands obtained in this study showed increased DNA concentration, which can justify its use in routine assessments.

Finally, since other factors may compromise results (e.i. stool consistency, medication use, stool conservation, the presence of other parasites in the samples, etc.), further studies are necessary to evaluate our protocol in the future.

\section{CONCLUSIONS}

In conclusion, our results have indicated that the extraction technique, which mixed glass beads with the GT, produced good results in the DNA extraction of S. mansoni eggs. With regard to PCR reamplification, despite its limitations, the use of two sequential amplifications per PCR to detect S. mansoni in feces may be a promising new tool.

\section{RESUMO}

Duas amplificações sequenciais por PCR para detecção de Schistosoma mansoni em amostras de fezes com baixa carga parasitária

A esquistossomose constitui grande problema de saúde pública, sendo que estimativas apontam para 200 milhões de pessoas infectadas no mundo e 700 milhões de pessoas em áreas de risco. No Brasil, existem áreas de alta, média e baixa endemicidade. Estudos demonstram 
ESPÍRITO-SANTO, M.C.C.; ALVARADO-MORA, M.V.; PINTO, P.L.S.; CARRILHO, F.J.; PINHO, J.R.R. \& GRYSCHEK, R.C.B. - Two sequential PCR amplifications for detection of Schistosoma mansoni in stool samples with low parasite load. Rev. Inst. Med. Trop. Sao Paulo, 54(5): 245-8, 2012.

que nas áreas endêmicas de baixa prevalência da infecção, a reduzida sensibilidade dos métodos parasitológicos torna-se evidente. Isto dificulta o diagnóstico, pela presença de resultados falso-negativos. O objetivo deste estudo foi a padronização de um protocolo de reamplificação da PCR (Re-PCR) para a detecção de Schistosoma mansoni em amostras com menos de 100 ovos por grama (opg) de fezes. Foram utilizados três métodos para ruptura dos envoltórios dos ovos de $S$. mansoni e duas técnicas de extração de DNA foram aplicadas. O DNA extraído foi quantificado e os resultados sugerem que a técnica de extração de melhor produtividade foi a que associa esferas de vidro a uma solução de isotiocianato de guanidina/fenol/clorofórmio (GT). Aplicou-se a RePCR, que demonstrou sensibilidade para a detecção de cinco ovos/500 mg de fezes artificialmente marcadas. Assim, essas novas ferramentas são potencialmente aplicáveis nas infecções por $S$. mansoni com baixa carga parasitária.

\section{ACKNOWLEDGMENTS}

This study was funded by the Fundação de Amparo à Pesquisa do Estado de São Paulo, processes 07/53457-7, 08/50461-6 and 10/52615-0. We thank Dr. Luciana Inacia Gomes, from Laboratório de Pesquisas Clínicas (Laboratory of Clinical Research), Instituto de Pesquisas René Rachou-Fiocruz - Belo Horizonte, Brazil, for her advice on the standardization process. Finally, we thank Miss Maria Cristina Conceição de Mello from LIM-06 FMUSP for her technical support in the biological cycle of S. mansoni.

\section{AUTHOR CONTRIBUTIONS}

MCCES participated in the design of the study, in the extraction and cleaning of $S$. mansoni eggs, standardization of the DNA extraction method and in the two sequential PCR amplifications. MVAM participated in the design of the study, the standardization of the DNA extraction method and in the two sequential PCR amplifications. PLSP participated in the design of the study and in the extraction and cleaning of $S$. mansoni eggs. FJC participated in the design of the study. MCCES, MVAM, JRRP and RCBG participated in the elaboration of the manuscript. All authors read and approved the final manuscript.

\section{REFERENCES}

1. Brasil. Ministério da Saúde. Secretaria de Vigilância em Saúde. Departamento de Vigilância Epidemiológica. Esquistossomose Mansoni. In: Doenças infecciosas e

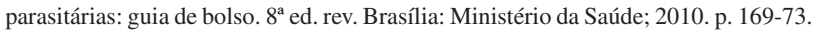

2. Chitsulo L, Engels D, Montresor A, Savioli L. The global status of schistosomiasis and its control. Acta Trop. 2000;77:41-51.

3. Chomczynski P, Sacchi N. Single-step method of RNA isolation by acid guanidinium thiocyanate-phenol-chloroform extraction. Anal Biochem. 1987;162:156-9.
4. Colley DG, Secor WE. A schistosomiasis research agenda. PLoS Negl Trop Dis. 2007; 1:e32.

5. Da Silva AJ, Bornay-Llinares FJ, Moura IN, Slemenda SB, Tuttle JL, Pieniazek NJ. Fast and reliable extraction of protozoan parasite DNA from fecal specimens. Mol Diagn. 1999;4:57-64.

6. Doenhoff MJ. A vaccine for schistosomiasis: alternative approaches. Parasitol Today. 1998;14:105-9.

7. Dresden MH, Payne DC. A sieving method for the collection of schistosome eggs from mouse intestines. J Parasitol. 1981; 67:450-2.

8. Ewing B, Green P. Base-calling of automated sequencer traces using phred. II. Error probabilities. Genome Res. 1998;8:186-94.

9. Ewing B, Hillier L, Wendl MC, Green P. Base-calling of automated sequencer traces using phred. I. Accuracy assessment. Genome Res. 1998;8:175-85.

10. Gomes LI, Dos Santos Marques LH, Enk MJ, de Oliveira MC, Coelho PM, Rabello A. Development and evaluation of a sensitive PCR-ELISA system for detection of schistosoma infection in feces. PLoS Negl Trop Dis. 2010;4:e664.

11. Gomes LI, Marques LH, Enk MJ, Coelho PM, Rabello A. Further evaluation of an updated PCR assay for the detection of Schistosoma mansoni DNA in human stool samples. Mem Inst Oswaldo Cruz. 2009;104:1194-6.

12. Musso O, Sommer P, Drouet E, Cotte L, Neyra M, Grimaud JA, et al. In situ detection of human cytomegalovirus DNA in gastrointestinal biopsies from AIDS patients by means of various PCR-derived methods. J Virol Methods. 1996;56:125.

13. Oliveira LM, Santos HL, Gonçalves MM, Barreto MG, Peralta JM. Evaluation of polymerase chain reaction as an additional tool for the diagnosis of low-intensity Schistosoma mansoni infection. Diagn Microbiol Infect Dis. 2010;68:416-21.

14. Pinto PLS, Floriano LD, Ferreira SC, Suto LM, Vellosa SAG. Purificação de ovos de Schistosoma mansoni a partir de vísceras de hamsters (Crycetus auratus) experimentalmente infectados. In: XIV Congresso da Sociedade Brasileira de Parasitologia, Goiânia, Brasil; 1995. p. 264. (Revista de Patologia Tropical; vol. 23, n. 2).

15. Pontes LA, Dias-Neto E, Rabello A. Detection by polymerase chain reaction of Schistosoma mansoni DNA in human serum and feces. Am J Trop Med Hyg. 2002;66:157-62

16. Rey L. Esquistossomíase mansônica: o parasito. In: Rey L. Bases da Parasitologia médica. $2^{\mathrm{a}}$ ed. Rio de Janeiro: Guanabara-Koogan; 2002. p. 153-82.

17. Ruiz-Tiben E, Hillyer GV, Knight WB, Gómez de Rios I, Woodall JP. Intensity of infection with Schistosoma mansoni: its relationship to the sensitivity and specificity of serologic tests. Am J Trop Med Hyg. 1979;28:230-6.

18. Teles HMS. Estudo parasitológico, da transmissão e dos impactos da profilaxia da esquistossomose mansônica no Município de Bananal, Estado de São Paulo, Brasil. [Tese]. Campinas: Instituto de Biologia, Unicamp; 2001.

Received: 12 November 2011

Accepted: 22 June 2012 